DOI (Article):https://doi.org/10.31108/2.2021.1.22.5

УДК 316/159.942

\title{
Губеладзе Ірина
}

\section{МЕТОДИ ТА ОРГАНІЗАЦІЯ ДОСЛІДЖЕННЯ ОСОБЛИВОСТЕЙ РЕАЛІЗАЦЇ̈ ПОЧУТТЯ ВЛАСНОСТІ В СОЦАЛЬНИХ ПРАКТИКАХ}

Губеладзе Ірина. Методи та організація дослідження особливостей реалізації почуття власності в соціальних практиках.

Bступ. 3 огляду на брак методик для вивчення почуття власності у статті обтрунтовується доиільність та стратегія дослідження психологічних особливостей реалізаиії почуття власності в соиіальних практиках.

Мета дослідження. Розробити комплекс методів емпіричного дослідження особливостей реалізачї почуття власності особи в сочіальних практиках.

Методи. Для проведення дослідження використовувався комплекс якісно-кількісних методів: асоціативний експеримент, фокус-групове дослідження, експертне опитування, опитування, контент-аналіз, математико-статистичні методи обробки даних, факторний та корелячійний аналізи для моделювання особливостей реалізацї̈ почуття власності в соціальних практиках.

Результати дослідження. Розроблено комплекс методів, який складається з трьох груп: 1) для визначення найбільш типових соиіальних практик володіння, в яких проявляється почуття власності; 2) для вивчення соціальних репрезентацій украӥнців щодо власності; 3) для вивчення психологічних особливостей реалізації почуття власності у різних сочіальних практиках та конструювання моделей такої реалізаиії. Обтрунтовано поетапну стратегію дослідження реалізачії почуття власності в сочіальних практиках.

Висновки. Поетапне слідування розробленій дослідницькій стратегї та використання описаних методів дає змогу комплексно і різнобічно дослідити почуття власності як сочіальнопсихологічний феномен та особливості його реалізащї в сочіальних практиках. Вибір використаних кількісних $і$ якісних методів зміманого дослідження є обтрунтованим і розкриває можливості узагальнення даних за допомогою допоміжної стратегії тріангуляиії. Запропонована модель дослідження може бути реплікована, а також доповнена у подальших наукових розвідках залежно від завдань та умов дослідження.

Ключові слова: почуття власності, соціальні практики, методи емпіричного дослідження, програма дослідження, дизайн дослідження.

Губеладзе Ирина. Методы и организация исследования особенностей реализации чувства собственности в социальных практиках.

Введение. Учитывая недостаток методик для изучения чувства собственности в статье обосновывается иелесообразность и стратегия исследования психологических особенностей реализачии чувства собственности в сочиальных практиках.

Цель исследования. Разработать комплекс методов эмпирического исследования особенностей реализации чувства собственности лица в социальных практиках.

Методы. Для проведения исследования использовался комплекс качественноколичественных методов: ассочиативный эксперимент, фокус-групповое исследование, экспертный опрос, опрос, контент-анализ, математико-статистические методы обработки данных, факторный и коррелящионный анализы для моделирования особенностей реализации чувства собственности в сочиальных практиках.

Результаты исследования. Разработан комплекс методов, который состоит из трех групп: 1) для определения наиболее типичных сочиальных практик владения, в которых проявляется чувство собственности; 2) для изучения социальных репрезентаций украинцев относительно собственности; 3) для изучения психологических особенностей реализации чувства собственности в различных социальных практиках и конструирования моделей такой реализации. Обосновано поэтапную стратегию исследования реализаџии чувства собственности в социальных практиках. 
Выводы. Поэтапное следование разработанной исследовательской стратегии и использования описанных методов позволяет комплексно и всесторонне исследовать чувство собственности как социально-психологический феномен и особенности его реализации в соииальных практиках. Выбор использованных количественных и качественных методов смешанного исследования является обоснованным и раскрывает возможности обобщения данных с помощью вспомогательной стратегии триангулящии. Предложенная модель исследования может быть реплицирована, а также дополнена в дальнейших научных поисках в зависимости от задач и условий исследования.

Ключевые слова: чувство собственности, социальные практики, методы эмпирического исследования, программа исследования, дизайн исследования.

Вступ. Дослідження проблеми власності у психологічній науковій літературі зосереджується на вивченні ставлення до власності. Західні дослідження сфокусовані на вивченні психологічної власності як чинника підвищення мотивації співробітників організації (Avey, Avolio, Crossley\& Luthans, 2009; Pierce, Kostova \& Dirks, 2002; Pierce, Jussila, \& Li, 2018), як чинника споживчої поведінки (Kirk, Peck \& Swain, 2018; Peck \& Shu, 2018); потреби у власності (Бурменко \& Карнышев, 2003; Луценко, 2012; Хазратова, 2009), елемента економічної соціалізації (Дембицька, 2018) та особливостей ставлення до грошей (Карамушка \& Ходакевич, 2017). Водночас у своєму дослідженні ми обгрунтовуємо авторську концепцію реалізації почуття власності в соціальних практиках, що потребує розробки і обгрунтування відповідного комплексу методів і методик, які дозволили б здійснити емпіричне дослідження у відповідності до поставлених завдань.

Аналіз літератури показав, що не існує спеціалізованих методик для вивчення почуття власності як генералізованого соціально-психологічного явища. Тим паче бракує відповідного інструментарію для вивчення реалізації почуття власності. Така методологічна складність поставила перед нами завдання - розробити відповідний комплекс методів і методик та спроєктувати авторський дизайн дослідження.

Мета дослідження. Представити комплекс методів емпіричного дослідження особливостей реалізації почуття власності особи в соціальних практиках.

Завдання дослідження. Для досягнення поставленої мети було визначено низку завдань: 1) проаналізувати наявний інструментарій для дослідження реалізації почуття власності в соціальних практиках; 2) здійснити поетапний опис стратегії організації емпіричного дослідження; 3) представити методичну базу емпіричного дослідження психологічних особливостей реалізації почуття власності в соціальних практиках.

Методи та організація дослідження. Для дослідження психологічних особливостей реалізації почуття власності в соціальних практиках нами було використано як якісні, так і кількісні методи збору та обробки інформації.

Для розв'язання поставлених завдань було обрано стратегію дослідження та розроблено відповідну програму дослідження, яка включала кілька етапів:

- ідентифікація сфер реалізації почуття власності, особливостей його прояву, мотивації психологічного привласнення та психологічних наслідків;

- визначення соціальних репрезентацій власності в уявленнях українців;

- виокремлення типових соціальних практик, в яких можлива реалізація почуття власності особи. Ми визначаємо їх як соціальні практики володіння (Губеладзе, 2020);

- розробка моделей реалізації почуття власності в соціальних практиках (емпірична верифікація моделей).

Запропонований комплекс включає низку методів: асоціативний експеримент 3 метою вивчення сфер реалізації почуття власності, особливостей його прояву, мотивації психологічного привласнення та психологічних наслідків; фокус-групове дослідження для 3'ясування типових соціальних практик та особливостей їх прояву; експертне опитування для уточнення переліку найбільш типових соціальних практик володіння; опитування; контент-аналіз для обробки даних асоціативного експерименту та фокус-групового 
дослідження; математико-статистичні методи обробки даних, фракторний та корелячійний аналізи для моделювання особливостей реалізації почуття власності в соціальних практиках.

Результати дослідження. Розглянемо кожен з етапів та методів окремо.

Етап 1. Асоиіативний експеримент було проведено серед 150 осіб. Основні питання, які пропонувалися опитуваним: 1) «Назвіть 10-20 слів або словосполучень, які у вас асоціюються зі словом «власність»; 2) «Назвіть кілька прикладів того, що ви можете назвати своїм: Моє (мій, моя, мої)»; 3) «Назвіть кілька прикладів того, що ви можете назвати своїм: Наше (наш, наша, наші)»; 4) «Що для вас означає володіти чимось? 3 чого складається ваше почуття власності?»; 5) «Як ви відчуваєте, що щось належить саме вам?»; 6) «Як ви відчуваєте різницю між тим, що належить виключно Вам (позначено словами «мій», «моя», «моє», «мої») і тим, що належить ще комусь (позначено словами «наш», «наша», «наше», «наші»)?»; 7) «Наведіть приклади, коли ви фактично не володієте чимось, але до чого маєте певне почуття власності»; 8) «Назвіть приклади, коли ви фактично володієте чимось, але маєте слабке почуття власності до цих об'єктів»; 9) «Що дає людині відчуття своєї власності?». Отримані дані аналізувалися з урахуванням віку, статі та місця проживання (сільська, міська місцевість) респондентів.

Використання таких відкритих питань дало нам змогу окреслити проблемне поле розуміння і соціальних репрезентацій українців щодо поняття «власність» та «володіти» й окреслити основні мотиви психологічного привласнення чи володіння.

Етап 2. Фокус-групові дослідження на предмет визначення найбільш типових соціальних практик, в яких можлива реалізація почуття власності.

Проведення фокус-груп серед іноземних магістрантів та аспірантів дало змогу окреслити певні соціокультурні особливості реалізації почуття власності в соціальних практиках.

Для верифікації соціальних практик володіння нами було проведено 10 фокус-груп, до яких було залучено 108 учасників. Це були студенти-психологи, які здобувають ступінь бакалавра (IV курс) та ступінь магістра. У кожній групі працювало 10-11 учасників. Їм пропонувалося виокремити найбільш поширені і типові соціальні практики володіння у відповідній сфері та обговорити особливості їхнього прояву. Кожна фокусгрупа працювала над окремою сферою реалізації почуття власності.

Оскільки учасниками фокус-груп були так би мовити пересічні громадяни, які не $\epsilon$ фахівцями 3 теорії соціальних практик чи економічної психології, їм давалася пояснювальна частина, що таке соціальні практики, які їхні виразні особливості, що таке почуття власності і соціальні практики володіння. Наводилися приклади, в яких сферах може реалізовуватися почуття власності. Далі в ході обговорення учасники визначали найбільш типові соціальні практики володіння у відповідній сфері. Обгрунтовували, як ми відчуваємо втрату і що може посилювати переживання почуття власності в даній сфері. Учасникам важливо було розуміти, що соціальна практика - це лише елемент, частина серед усього різноманіття дій, які може здійснювати особа. I варто відрізняти ії від вчинку, дії, правила, ритуалу за певними ознаками. Оскільки соціальні практики є фоновими і рутинними, їх важко відрефлексувати і відчути, то для ефективної роботи у фокус-групі було застосовано техніки відсторонення, опису та інтерпретації (Волков, \& Хархордин, 2008, 24-25). У результаті роботи кожної фокус-групи було створено і обгрунтовано перелік із 4-6 соціальних практик у кожній запропонованій сфері життєдіяльності особи. Утворений перелік на наступному етапі пропонувався для експертного опитування.

Етап 3. Експертне опитування. Наступний етап дослідження полягав у визначенні найбільш відповідних соціальних практик володіння у кожній зі сфер. Визначені під час фокус-груп соціальні практики володіння було згруповано і запропоновано 10 експертам для оцінки на відповідність визначенню соціальних практик. Експертами виступили 
психологи-науковці, які займаються вивченням соціальних практик. Оцінка ступеня узгодженості думок експертів визначалася за допомогою коефіцієнта конкордації.

Експертна-оцінка послідовно включала такі основні етапи: 1) формування групи фахівців-експертів; 2) підготовка бланку опитувальника для експертів; 3) опитування експертів; 4) обробка даних; 5) статистична обробка експертних оцінок. Експерти обиралися за критеріями їх високої професійної кваліфікації (кандидати і доктори психологічних наук, які мають значний досвід роботи у області соціальної психології), компетентність щодо соціальних практик, незацікавленість у результатах експертизи і об'єктивність. Через карантинні обмеження і дистанційну форму роботи опитування експертів здійснювалося онлайн шляхом розсилання їм анкет.

Експертам необхідно було прорангувати кожну із запропонованих соціальних дій, пов'язаних із проявом почуття власності у різних сферах відповідно до критеріїв визначення саме соціальних практик. Рангова оцінка зводиться до визначення вагомості (значущості) кожного показника. Найбільш важливий показник позначають рангом $\mathrm{R}=1$, a найменш значущий - рангом $\mathrm{R}=\mathrm{n}$, де $\mathrm{n}-$ кількість запропонованих показників. Чим ближче значення коефіцієнта конкордації $\mathrm{W}$ до 1, тим краще погодженість думок експертів, а значення менше за 0,5-0,7 є незадовільними. Значущість коефіцієнта конкордації визначається за критерієм $\chi^{2}$ Пірсона.

3 огляду на статистичну істотність отриманих коефіцієнтів конкордації, ми доходимо висновку про високу узгодженість думок експертів, що свідчить про коректність проведеного дослідження і можливості вільно поширювати отримані дані для побудови подальшого дослідження. Виокремлені у такий спосіб соціальні практики володіння будуть використані нами для подальшого вивчення i, зокрема, у створенні моделей реалізації почуття власності в соціальних практиках.

Етап 4. Теоретичне моделювання та емпірична верифікація моделей реалізації почуття власності. За основу розроблюваного опитувальника було взято опитувальники для дослідження психологічної власності в організаціях (Avey, Avolio, Crossley \& Luthans, 2009; Pierce, Kostova \& Dirks, 2002; Pierce, Jussila, \& Li, 2018). Їх розробники вважають, що почуття власності можливо вивчати через опис його складових: належність, самооцінка, самоінвестування, відповідальність тощо. Усі ці елементи були закладені в структуру валідизованих опитувальників.

Було опитано 349 осіб. До кожної сфери було запропоновано одну найбільш типову практику (яку визначили за результатами роботи фокус-груп та експертного опитування). Кожна із практик пропонувалася групам у трьох часових перспективах або станах: актуальний (переживання щодо володіння зараз), перспективний (мотивація привласнення, хочу мати) і загроза втрати. Описи ситуації наведені у таблиці 1.

До кожної такої ситуації пропонувалася низка питань, які дають змогу відстежити стан і переживання респондентів. Опитуваним необхідно було оцінити за 5-ти бальною шкалою міру прояву такого переживання (часто/не часто, актуально/не актуально тощо), де 1 - негативний полюс, а 5 - позитивний полюс.

1. Наскільки часто вона трапляється у вашому житті.

2. Наскільки такі дії цінні, значущі, важливі для вас.

3. Наскільки ці дії актуальні для вас на даний момент життя.

4. Протягом якого періоду такі дії є у вашому житті (тривалість) (з'явились зовсім нещодавно).

5. Наскільки ваші переживання з приводу таких дій є інтенсивними.

6. Наскільки така ситуація є буденною, типовою для вас.

Для визначення і побудови моделі реалізації почуття власності у запропонованій практиці, респондентам необхідно було оцінити, що вони відчувають у такій ситуації щодо вказаного об’єкту власності (наприклад, свого тіла, території, грошей, стосунків тощо). 
Типові соціальні практики володіння

\begin{tabular}{|c|c|c|c|}
\hline $\begin{array}{c}\text { Сфери i } \\
\text { практики }\end{array}$ & Актуальний стан & Перспективний стан & Загроза втрати \\
\hline Tіло & $\begin{array}{l}\text { Ви } \\
\text { доглядаєте зоденно } \\
\text { тілом, двоїм } \\
\text { особистої } \\
\text { дбаєте простеск безпеку та та } \\
\text { здоров'я свого тіла }\end{array}$ & $\begin{array}{l}\text { Уявіть, що ви хотіли б } \\
\text { ретельніше доглядати за } \\
\text { своїм тілом, наприклад, } \\
\text { частіше відвідувати салони } \\
\text { краси чи зробити нову } \\
\text { зачіску, займатися спортом } \\
\text { для підтримки здорового } \\
\text { тіла тощо }\end{array}$ & $\begin{array}{l}\text { Уявіть, що у вашому міст } \\
\text { вимкнули воду і ви вже } \\
\text { довгий час не маєте змоги } \\
\text { нормально доглядати за } \\
\text { своїм тілом, регулярно } \\
\text { дотримуватися гігієнічних } \\
\text { процедур. Салони краси } \\
\text { спортзали закриті }\end{array}$ \\
\hline Гроші & $\begin{array}{l}\text { Ви заробляєте гроші, } \\
\text { плануєте свої витрати } \\
\text { і ведете бюджет }\end{array}$ & $\begin{array}{l}\text { Уявіть, що ви хочете } \\
\text { збільшити обсяг своїх } \\
\text { прибутків, } \\
\text { більше, щоб мати більше } \\
\text { грошей }\end{array}$ & $\begin{array}{l}\text { Уявіть, що хтось поцупив } \\
\text { ваші гроші } 3 \text { гаманця чи } \\
\text { картки. Або на роботі вам не } \\
\text { виплатили заробітну плату } \\
\text { вже не виплатять }\end{array}$ \\
\hline Ідеї, думки & $\begin{array}{l}\text { У вас є свої творчі } \\
\text { ідеї, думки. Або ви } \\
\text { створюєте } \\
\text { творчий } \\
\text { (наприклись } \\
\text { картини, мадукт } \\
\text { вірші, записуєте цікаві } \\
\text { відео, вигадали новий } \\
\text { рецепт...) і це дуже } \\
\text { важливо для вас }\end{array}$ & $\begin{array}{l}\text { Уявіть, що ви б хотіли } \\
\text { навчитися робити якісь } \\
\text { творчі речі (наприклад, } \\
\text { малювати картини, писати } \\
\text { вірші, записувати цікаві } \\
\text { відео, вигадувати нові } \\
\text { рецепти...), оформлювати } \\
\text { свої думки і цікаві тексти }\end{array}$ & $\begin{array}{l}\text { Уявіть, що хтось без дозволу } \\
\text { i збереження авторського } \\
\text { права поширює ваші думки } \\
\text { ідеї чи творчі продукти } \\
\text { (наприклад, фото, відео } \\
\text { пости, вірші...) }\end{array}$ \\
\hline Територія & 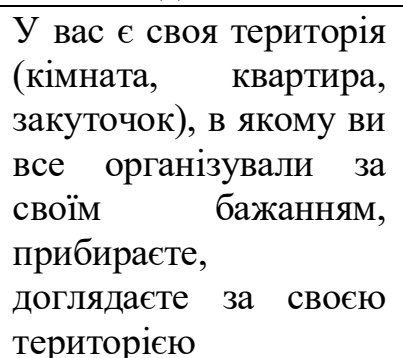 & 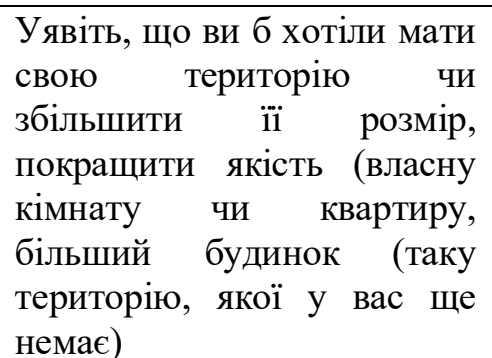 & $\begin{array}{l}\text { Уявіть, що хтось інший } \\
\text { порушує ваш простір } \\
\text { постійно займаючи вашу } \\
\text { територію (наприклад, хтось } \\
\text { заходить в кімнату бе } \\
\text { дозволу) }\end{array}$ \\
\hline Держсава & 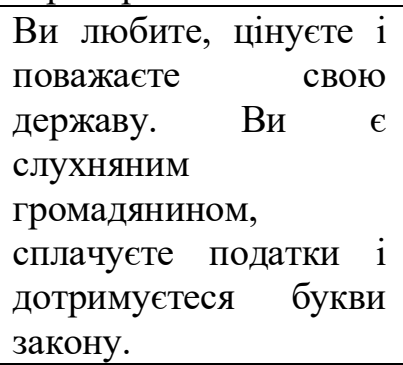 & 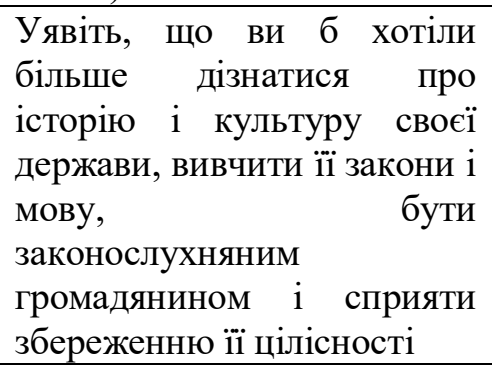 & $\begin{array}{l}\text { Уявіть, що хтось втрутився } \\
\text { на територію вашої держави } \\
\text { порушує ії закони. } \\
\begin{array}{l}\text { можете } \\
\text { державу }\end{array}\end{array}$ \\
\hline $\begin{array}{l}\text { Віртуальний } \\
\text { простір }\end{array}$ & $\begin{array}{l}\text { Ви маєте свій } \\
\text { особистий } \\
\text { віртуальний простір } \\
\text { (наприклад, аккаунт, } \\
\text { групу чи сторінку в } \\
\text { соціальних мережах). } \\
\text { Ви дбаєте про його } \\
\text { наповнення, пишете } \\
\text { цікаві для вас } \\
\text { матеріали, виставляєте } \\
\text { важливі для вас фото і } \\
\text { відеоматеріали }\end{array}$ & $\begin{array}{l}\text { Уявіть, що ви б хотіли } \\
\text { створити свій унікальний } \\
\text { віртуальний } \\
\text { (наприклад, аккаунт, групу } \\
\text { чи сторінку в соціальних } \\
\text { мережах). Зробити його } \\
\text { впізнаваним, цікавим, } \\
\text { яскравим. Можливо, вести } \\
\text { власний блог чи канал }\end{array}$ & 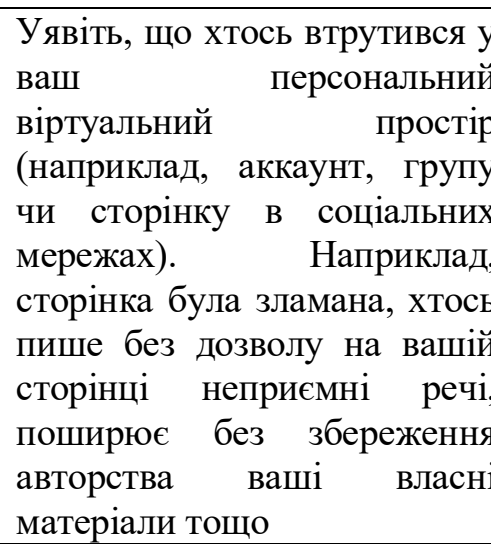 \\
\hline
\end{tabular}


Продовження таблиці 1

\begin{tabular}{|c|c|c|c|}
\hline Речі & $\begin{array}{l}\text { Ви маєте улюблену, } \\
\text { важливу для вас річ. } \\
\text { Ви дбаєте про неї, } \\
\text { зберігаєте їі }\end{array}$ & $\begin{array}{l}\text { Уявіть, що ви дуже хочете } \\
\text { мати (купити, отримати в } \\
\text { подарунок) якусь важливу, } \\
\text { цінну і привабливу для вас } \\
\text { річ }\end{array}$ & $\begin{array}{l}\text { Уявіть, що хтось без } \\
\text { дозволу взяв вашу } \\
\text { улюблену, дорогу для вас } \\
\text { річ і, можливо, навіть } \\
\text { зіпсував їі }\end{array}$ \\
\hline $\begin{array}{l}\text { Соціальні } \\
\text { контакти }\end{array}$ & $\begin{array}{lr}\text { У вас } є \text { важливі для } \\
\text { вас } & \text { соціальні } \\
\text { стосунки } & \text { (з } \\
\text { ріднзямими, } & \text { коханою } \\
\text { людиною), } & \text { ви } \\
\text { проводите час } & \text { разом, } \\
\text { спілкуєтеся. } & \text { Ці } \\
\text { стосунки } & \text { приносять } \\
\text { вам задоволення }\end{array}$ & $\begin{array}{l}\text { Уявіть, що ви } \\
\text { познайомитися хотіли } \\
\text { налагодити стосунки } \\
\text { якоюсь важливою, цікавою } \\
\text { для вас } \\
\text { підтримувати } \\
\text { ï }\end{array}$ & $\begin{array}{lrr}\text { Уявіть, що } & \text { хтось } \\
\text { втрутився } & \text { у } & \text { ваші } \\
\text { стосунки } 3 \text { важливою для } \\
\text { вас людиною. Можливо, } \\
\text { навіть ці } \\
\begin{array}{l}\text { погіршилися стосунки } \\
\text { зіпсовані }\end{array}\end{array}$ \\
\hline Робоче місце & $\begin{array}{l}\text { У вас є своє робоче } \\
\text { місце (місце для } \\
\text { навчання) у вашій } \\
\text { організації, компанії. } \\
\text { Ви цінуєте і любите } \\
\text { свою роботу, робоче } \\
\text { місце, колег }\end{array}$ & $\begin{array}{l}\text { Уявіть, що ви б хотіли } \\
\text { знайти цікаву роботу в } \\
\text { хорошій компанії, зі } \\
\text { зручним графіком і доброю } \\
\text { заробітною платою }\end{array}$ & $\begin{array}{l}\text { Уявіть, що хтось хоче } \\
\text { нечесним } \\
\text { зайняти ваше шлом } \\
\text { місце або ліквідувати } \\
\text { його }\end{array}$ \\
\hline $\begin{array}{l}\text { Час, } \\
\text { планування }\end{array}$ & $\begin{array}{l}\text { Ви плануєте свій час, } \\
\text { знаєте свій розклад } \\
\text { щонайменше на день }\end{array}$ & $\begin{array}{lcr}\text { Уявіть, що ви б хотіли бути } \\
\text { більш } & \text { пунктуальним, } \\
\text { планувати } & \text { свій } & \text { день, } \\
\text { тиждень } & \text { i } & \text { чітко } \\
\text { дотримуватися } & \text { плану, } \\
\text { економлячи свій час } & \end{array}$ & $\begin{array}{l}\text { Уявіть, що ви спланували } \\
\text { свій день і кожна хвилина } \\
\text { для вас важлива, але ваш } \\
\text { знайомий спізнився і ви } \\
\text { зустрілися пізніше. Через } \\
\text { це вам довелося } \\
\text { перенести наступну } \\
\text { зустріч. Ви розумієте, що } \\
\text { план на день може } \\
\text { рухнути і ви не будете } \\
\text { контролювати свій час }\end{array}$ \\
\hline
\end{tabular}

Необхідно оцінити, якою мірою в межах пари антонімів можна описати запропоновані переживання, в діапазоні від 1 до 5, де 1 - це один полюс (перше слово), а 5 - другий полюс (протилежне слово).

- Безвідповідальність (1 бал) - відповідальність (5 балів).

- Сум - радість.

- Сором - гордість.

- Відсутність бажання мати свій/свої ситуації) - сильне бажання мати свій/свої (об'єкт власності).

(об'єкт власності залежно від

- Відразу до своїх (об'єкт власності)- задоволення ними.

- Страх, тривогу - спокій.

- Зневагу, ненависть до свого/своїх (об’єкт власності) - повагу, любов до них.

- Злість, агресію - позитивний настрій.

- Байдужість - прихильність.

- Небезпеку - безпеку.

- Дискомфорт - комфорт.

- Бажання, потребу просити про допомогу інших - сильне бажання, потребу створювати (об'єкт власності) самостійно.

- Відсутність бажання продемонструвати іншим свої (об'єкт власності) сильне бажання продемонструвати іншим свої (об'єкт власності). 
- Відсутність потреби заявити і відстояти своє право на власні___ (об'єкm власності) - сильну потребу заявляти і відстоювати своє право на власні (об' $\mathrm{\epsilon} \kappa \mathrm{km}$ власності).

- Відсутність бажання позначити, що це мої (об’'єкт власності) - сильне бажання.

- Відсутність бажання вкладати зусилля, сили та енергію в те, щоб мати i створювати свої (об'єкт власності) - сильний прояв такого бажання.

- Я мало цікавлюся, прагну дізнатися про те, як формулювати, створювати власні (об 'єкт власності) - я знаю, прагну дізнатися більше, як формулювати, створювати (об'єкт власності).

- Відчуження, дистанціювання від людей, які мають власні (об' $\mathrm{\epsilon km}$ власності) - я відчуваю, що належу до людей, які мають власні (об'ект власності).

- Слабке відчуття того, що мої (об’єкт власності) належать мені (не мої) сильне відчуття того, що мої (об'єкт власності) належать мені (мої).

- Проблеми, пов'язані з моїми (об’єкт власності), як спільні 3 кимось проблеми, інші мають допомогти мені у їх вирішенні - Проблеми, пов'язані з моїми (об'єкт власності), як мої власні, особисті проблеми.

Запропонований перший блок питань дає змогу визначити ступінь актуальності відповідної практики, iї типовість і буденність, цінність для особи та тривалість практикування. Такі дані дають основу для подальшого дослідження і моделювання особливостей реалізації почуття власності в соціальних практиках залежно від вказаних показників. Для цього ми використали кореляційний аналіз. Другий блок питань вже пов'язаний $з$ емоційними переживаннями щодо володіння та реалізації почуття власності в соціальних практиках. В його основу покладено теоретичні засади теорії психологічної власності Дж.П’єрса (Pierce, Kostova \& Dirks, 2002).

Створений комплекс методів емпіричного дослідження психології реалізації почуття власності особи в соціальних практиках спирається на використання різних методів збору інформації (методологічна тріангуляція), що сприяло конструюванню комплексного бачення феномену почуття власності, особливостей його реалізації в соціальних практиках та досягненню валідності результатів дослідження.

Висновки. Поетапне слідування розробленій дослідницькій стратегії та використання описаних методів дає змогу комплексно і різнобічно дослідити почуття власності як соціально-психологічний феномен та особливості його реалізації в соціальних практиках. Вибір використаних кількісних і якісних методів змішаного дослідження $є$ обгрунтованим і розкриває можливості узагальнення даних за допомогою допоміжної стратегії тріангуляції. Запропонована модель дослідження може бути реплікована, а також доповнена у подальших наукових розвідках залежно від завдань та умов дослідження.

Перспективи подальших досліджень вбачаємо у можливості подальшого емпіричного вивчення особливостей трансформації почуття власності та особливостей його прояву у різних соціокультурних контекстах. Створення комплексу методів емпіричного дослідження психологічних особливостей реалізації почуття власності в соціальних практиках відкриває перспективи розробки дослідницької програми вивчення чинників та механізмів реалізації почуття власності у соціальних практиках.

\section{Література}

1. Бурменко, Т. Д., Карнышев, А.Д. (2003). Собственность: психолого-экономический анализ. Иркутск: издво БГУЭП. 2003.

2. Волков, В., \& Хархордин, О. (2008). Теория практик. Санкт-Петербург: Изд-во Европейского университета в Санкт-Петербурге.

3. Губеладзе, І.Г. (2020). Соціальні практики володіння як простір реалізації почуття власності. Наукові студї із соціальної та політичної психологї. 46 (49).242-250. https://doi.org/10.33120/ssj.vi46(49).173 
4. Карамушка, Л. М., Ходакевич, О. Г. (2017). Психологічні особливості ставлення студентської молоді до грошей: монографія. Київ: КНЕУ.

5. Луценко, М.Ю. (2012). Обгрунтування та опис авторської методики «Фрустрація потреби у власності». Практична психологія та соиіальна робота. 9 (162). 15-23.

6. Соціально-психологічне забезпечення економічної соціалізації молоді: монографія (2018). За ред. Н.М. Дембицької. Київ: Інститут психології імені Г.С. Костюка НАПН України.

7. Хазратова, Н.В. (2009). Психологічна природа почуття власності. Соціальна психологія. 5, $103-110$.

8. Avey, J.B., Avolio, B.J., Crossley, C.D., \& Luthans, F. (2009). Psychological ownership: Theoretical extensions, measurement and relation to work outcomes. Journal of Organizational Behavior. 30, $173-191$. https://doi.org/10.1002/job.583.

9. Kirk, C.P., Peck, J., \& Swain, S.D. (2018). Property Lines in the Mind: Consumers' Psychological Ownership and Their Territorial Responses. Journal of Consumer Research. 45. 1. 148-168. https://doi.org/10.1093/jcr/ucx111.

10. Pierce, J.L., Kostova, T., \& Dirks, K.T. (2002). The state of psychological ownership: Integrating and extending a century of research. Review of General Psychology. 7(1). 84-107. DOI: 10.1037//1089-2680.7.1.84.

11. Pierce, J.L., Jussila, I., \& Li, D. (2018). Development and Validation of an Instrument for Assessing Collective Psychological Ownership in Organizational Field Settings. Journal of Management \& Organization. 24. 6.776-792. https://doi.org/10.1017/jmo.2016.66.

12. Peck, J., Shu, S.B. (2018). Psychological Ownership and Consumer Behavior. Springer International Publishing. 263 (278).

\section{References}

1. Burmenko, T. D., \& Karnyshev, A. D. (2003). Sobstvennost: psikhologo-ekonomicheskii analiz [Property: psychological and economic analysis]. Izd-vo BGUEP. 2003. [in Russian]

2. Volkov, V., \& Kharkhordyn, O. (2008). Teoryya praktyk [Theory of practice]. Izd-vo. Evropeiskogo universiteta v Sankt-Peterburge. [in Russian]

3. Gubeladze, I. G. (2020). Sotsialni praktyky volodinnya yak prostir realizatsiyi pochuttya vlasnosti [Social practices of ownership as a space for the realization of a sense of ownership]. Naukovi studiyi iz sotsialnoyi ta politychnoyi psykhologiyi.46(49). 242-250. https://doi.org/10.33120/ssj.vi46(49).173[in Ukrainian]

4. Karamushka, L. M., \& Khodakevych, O. G. (2017). Psykhologichni osoblyvosti stavlennya studentskoyi molodi do groshei: monografiya [Psychological features of students' attitude to money].KNEU. [in Ukrainian]

5. Lutsenko, M. Yu. (2012). Obrruntuvannya ta opys avtorskoyi metodyky «Frustratsiya potreby u vlasnosti» [Substantiation and description of the Frustration of the Need for Property questionnaire]. Praktychna psykhologiya ta sotsialna robota. 9(162). 15-23. [in Ukrainian]

6. Dembytska, N. M. (Ed.). (2018). Sotsialno-psykhologichne zabezpechennya ekonomichnoyi sotsializatsiyi molodi: monografiya [Socio-psychological support for economic socialization of youth]. Instytut psykhologiyi imeni G. S. Kostyuka NAPN Ukrayiny. [in Ukrainian]

7. Khazratova, N. V. (2009). Psykhologichna pryroda pochuttya vlasnosti [The psychological nature of ownership]. Sotsialna psykhologiya. 5, 103-110. [in Ukrainian]

8. Avey, J. B., Avolio, B. J., Crossley, C. D., \& Luthans, F. (2009). Psychological ownership: Theoretical extensions, measurement and relation to work outcomes. Journal of Organizational Behavior, 30, 173-191. https://doi.org/10.1002/job.583

9. Kirk, C.P., Peck, J., \&Swain, S.D. (2018). Property Lines in the Mind: Consumers' Psychological Ownership and Their Territorial Responses. Journal of Consumer Research. 45. 1. 148-168. https://doi.org/10.1093/jcr/ucx111

10. Pierce, J.L., Kostova, T., \& Dirks, K.T. (2002). The state of psychological ownership: Integrating and extending a century of research. Review of General Psychology. 7(1). 84-107. DOI: 10.1037//1089-2680.7.1.84

11. Pierce, J.L., Jussila, I. \&, D. (2018). Development and Validation of an Instrument for Assessing Collective Psychological Ownership in Organizational Field Settings. Journal of Management \& Organization. 24. 6.776792. https://doi.org/10.1017/jmo.2016.66

12. Peck, J., \& Shu, S.B. (2018). Psychological Ownership and Consumer Behavior. Springer International Publishing. 263 (278).

\section{Hubeladze, Iryna. Methods and organization of research on the realization of sense of ownership in social practices. \\ Introduction. Given the lack of methods for studying the sense of ownership, the article} substantiates the feasibility and strategy of studying the psychological features of the realization of sense of ownership in social practices.

Aim. To develop a set of methods for empirical research of psychological features of realization of person's sense of ownership in social practices.

Methods. A set of qualitative and quantitative methods, which included: associative experiment, focus group method, expert survey, interview, content analysis, mathematical and statistical analyses, as 
well as factor and correlation analyses to model the features of the realization of sense of ownership in social practices.

Results. The set of methods proposed by the author consisted of three groups of methods, which aimed at: 1) determining the most typical social practices of ownership, in which a sense of ownership was manifested; 2) studying social ideas of Ukrainians regarding property; 3) studying the psychological features of the realization of sense of ownership in various social practices and constructing models of this realization. The author gives a logical substantiation of a step-by-step strategy of research into the realization of sense of ownership in social practices.

Conclusions. The proposed research strategy and methods allow exploring a complex social and psychological phenomenon of sense of ownership and its realization in social practices. The quantitative and qualitative methods of the mixed research are effective and offer the possibility of generalization of the data by means of auxiliary strategy of triangulation. The proposed research model can be replicated and supplemented in further scientific research depending on the objectives and conditions of the study.

Key words: sense of ownership, social practices, empirical research methods, research program, research design.

\section{Відомостіпроавтора}

Губеладзе Ірина Гурамівна, кандидат психологічних наук, старший науковий співробітник Інституту соціальної та політичної психології НАПН України, м. Київ, Україна.

Hubeladze, Iryna, PhD in Psychology, Senior Researcher, Institute of Social and Political Psychology of the NAES of Ukraine, Kyiv, Ukraine.

E-mail: irynagubeladze@gmail.com

ORCID ID: https://orcid.org/0000-0001-8023-6408

Отримано 15 лютого $2021 \mathrm{p}$.

Рецензовано 1 березня 2021 р.

Прийнято 5 березня 2021 р.

DOI (Article):https://doi.org/10.31108/2.2021.1.22.6

UDK: 159.9:613

\section{Dolinny, Sergiy}

\section{PSYCHOLOGICAL TRENDS IN PSYCHOSOMATIC HEALTH MAINTAINNG}

\section{Dolinny, Sergiy. Psychological trends in psychosomatic health maintaining.}

Introduction. The problem of interrelations of psychological status of a personality and psychosomatic health is examined.

Aim of the article is to substantiate psychological trends in the context of maintaining the psychosomatic health of the individual. It is shown that maintaining psychosomatic health is possible on condition of correspondence of physiological, personal and social norms of the psychological potential of a person, the basis of which is constant. The author analyzes potential risks in the development of somatic diseases according to the destruction of a person's psychic.

Conclusion. Features and methods of maintaining the psychosomatic health of the individual are shown. The restructuring of the motivational sphere is due to the dominance of such leading motives, which are focused mainly on maintaining and restoring health, are aimed at self-determination of resources of psychological stability of each participant, to change attitudes to the problem-conflict situation, to develop self-actualization and formation of appropriate semantic orientations.

Key words: psychological tendencies, personality stability, psychosomatic health, characterological and personal traits, conflicts. 